\title{
Foraging loads of stingless bees and utilisation of stored nectar for pollen harvesting*
}

\author{
Sara D. LEONHARDT ${ }^{\mathrm{a}}$, Kai DWORSCHAK ${ }^{\mathrm{a}}$, Thomas ELTZ ${ }^{\mathrm{b}}$, Nico BLÜTHGEN ${ }^{\mathrm{a}}$ \\ ${ }^{a}$ Department of Animal Ecology and Tropical Biology, Biozentrum, University of Würzburg, Am Hubland, \\ 97074 Würzburg, Germany \\ ${ }^{\mathrm{b}}$ Institute of Neurobiology, Universitätsstr. 1, University of Düsseldorf, 40225 Düsseldorf, Germany
}

Received 9 May 2006 - Revised 4 July 2006 - Accepted 7 July 2006

\begin{abstract}
We compared nectar, pollen and resin loads of individual workers among colonies from six Trigona species in Sabah, Borneo. Individual bees rarely collected large amounts of both nectar and pollen during the same foraging trip. Instead, comparison of crop contents across departing, flower-visiting, and returning bees suggests that pollen-collecting workers often carried highly concentrated nectar in their crop upon nest departure. During their foraging trip, this crop nectar volume decreased progressively until crops were largely empty when they returned to their nest. Individually marked pollen foragers carried highly concentrated nectar when they left their nest, while crops and corbiculae from marked nectar foragers were empty upon departure. We suggest that a large proportion of previously stored and highly concentrated nectar may be required for pollen adhesion to corbiculae and/or serve as fuel during foraging on nectarpoor flowers.
\end{abstract}

foraging behaviour / nectar / pollen load / resin / Trigona

\section{INTRODUCTION}

Stingless bees (Apidae: Meliponini) are common in tropical rainforests and are crucial pollinators of a large proportion of tropical plant species, potentially summing up to one fifth of the local angiosperm flora (Wilms et al., 1996; Corlett, 2004). Stingless bees of the genus Trigona are highly social and live in perennial colonies with up to several thousand individuals (Wille, 1983; Roubik, 1989, 1993). As in honeybees, their principal resources are pollen and nectar, but they also collect materials such as resin, water, sap, wax, honeydew, extrafloral nectar, mud, salts, animal protein, and fungal spores for nutrition or nest-building materials (Roubik, 1989; Eltz et al., 2002). Pollen is the sole resource collected on many flowers (Roubik, 1989). Pollen

Corresponding author: N. Blüthgen,

bluethgen@biozentrum.uni-wuerzburg.de

* Manuscript editor: Stan Schneider is used to supply the protein requirements of the stingless bees' larvae and adults. It is provisioned to brood cells, but also exchanged between workers in a liquid suspension via trophallaxis (Sommeijer et al., 1985). Nectar carbohydrates are a main energy source, but in most apid bees nectar is additionally used for adhesion of pollen packages to their unique pollen transportation structure of the hind tibiae, the corbicula (Roubik, 1989).

Individual honeybees as well as bumblebees frequently gather both pollen and nectar during a single foraging trip (Benedek, 1976; Plowright and Galen, 1985; Worswick, 1988; Rana et al., 1997). This strategy of resource mixing may represent the most efficient way to harvest both resources. The presence of such mixed foraging in stingless bees has not yet been studied in detail, but it has been suggested that individual worker bees commonly specialise on either pollen or nectar during a single foraging trip or even during a 
whole foraging career (Sommeijer et al., 1983; Biesmeijer and Tòth, 1998), although individuals occasionally transport both full pollen and nectar loads (Roubik and Buchmann, 1984). However, crop loads may have been filled either during the foraging trip or before departure from the nest, hence observations of returning workers at nest entrances (e.g., Plowright and Galen, 1985; Roubik et al., 1995; Biesmeijer et al., 1999; Pierrot and Schlindwein, 2003) may not provide a full picture of the resources used and collected. Relatively few studies recorded the bees' loads during their foraging trip (Nagamitsu and Inoue, 1997; Rana et al., 1997) or upon departure from the nest (Gary and Lorenzen, 1976). Inoue et al. (1985) reported that Trigona minangkabu workers carried on average $0.15 \mu \mathrm{L}$ of $38 \%$ sugar solution in their crop upon nest departure, but returned with larger amounts of more diluted nectar $(2.2 \mu \mathrm{L}, 7 \%)$.

We studied patterns of separate vs. mixed resource collection of pollen, nectar and resin in workers of six Trigona species as well as the changes in crop loads during the foraging trip. For this purpose, we quantified nectar, pollen and resin loads of departing, flower-visiting and returning bees.

\section{MATERIALS AND METHODS}

\subsection{Study site and bee species}

The study took place at the Danum Valley Field

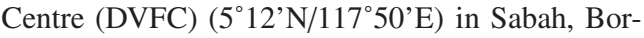
neo (Malaysia) in March-April 2004 and FebruaryApril 2005. The DVFC is located in the Danum Valley Conservation Area (DVCA) at the margin of open secondary vegetation (SV) and mature rainforest (RF). The DVCA covers $438 \mathrm{~km}^{2}$ of undisturbed dipterocarp lowland rainforest (Marsh and Greer, 1992). All bee colonies and studied plants were located within a three kilometer radius around the DVFC and included both vegetation types, SV and RF.

Six species of Trigona were observed at their nests: Trigona (Homotrigona) fimbriata melanotricha (one colony nesting in RF), T. (Odontotrigona) haematoptera (one colony in SV), T. (Tetragonula) collina (two colonies in RF), T. (Tetragonula) laeviceps (one colony in SV),
T. (Tetragonula) melanocephala (one colony in SV and one in RF), and T. (Tetrigona) binghami (one colony in RF). Individuals of these bee species were also observed while foraging on flowers of 14 plant species including ten native and four nonindigenous ones (Tab. I). We caught bees on plants between $0800 \mathrm{~h}$ and $1400 \mathrm{~h}$ and occasionally in the afternoon when bees rarely visited flowers except those of Pipturus. Nests were studied between $0800 \mathrm{~h}$ and $1200 \mathrm{~h}$ for at least two days (4 hours) per colony (Tab. II) with additional observations for T. melanocephala between $1400 \mathrm{~h}$ and $1700 \mathrm{~h}$. This colony was most easily accessed and therefore used for more detailed experiments and observations. In 2004 , we collected data at nests exclusively for returning foragers, whereas both departing and returning foragers were studied in 2005. Bees were caught with a butterfly net or a hand vacuum cleaner that was modified to keep bees in a small box padded with cotton to avoid injuries.

\subsection{Quantity and quality of foraging items}

Three types of resources carried by bees were distinguished: (a) nectar (including all fluids regurgitated from the crop), (b) pollen (on corbiculae only) and (c) resin (on corbiculae, possibly including all kinds of indistinguishable sticky substances, e.g. viscous extrafloral nectar). Nectar was extracted from the bees' crop by carefully squeezing them laterally and collecting the regurgitated nectar with microcapillary tubes (Gary and Lorenzen, 1976; Roubik and Buchmann, 1984; Roubik et al., 1995). Sugar content was measured with a hand-held refractometer corrected for temperature (Eclipse, Bellingham \& Stanley) to the nearest $0.5 \mathrm{~g} / \mathrm{g}$ sucrose equivalent. The size of pollen and resin loads $(L)$ on the bees' corbiculae was visually assessed in the field in relation to the size of the corbicula. The volume of a cube with a side length equal to the maximum corbicula width was considered as one unit $(L=1.0)$ for each bee, thus permitting an assessment of the pollen or resin load volume in relation to the corbicula's capacity independently of the bee's size. Values resulting from these measurements can be regarded as an estimation of the weight of the pollen load. We tested this for T. binghami, where we found a significant linear correlation (pollen load weight $[\mathrm{mg}] \approx 0.6 \cdot L ; r=0.98, P<0.001, \mathrm{n}=12$ pollen loads), confirming that the method of pollen 
Table I. Trigona species observed on flowers from indigenous plants (i) and non-indigenous plants (ni). Number of bee individuals measured $(n)$, resources collected by bees $(\mathrm{P}=$ pollen, $\mathrm{N}=$ nectar $)$, and volume and sugar concentration of nectar in crops (mean $\pm \mathrm{SD}$ ) shown, based on all workers where nectar was detected.

\begin{tabular}{|c|c|c|c|c|c|}
\hline Trigona species & Plant species visited & $n$ & & Crop load $[\mu \mathrm{L}]$ & Sugar $[\%]$ \\
\hline \multirow[t]{7}{*}{ T. binghami } & Archidendron jiringa (Fabaceae) (i) & 18 & $\mathrm{~N}$ & $0.76 \pm 0.52$ & $39.5 \pm 14.7$ \\
\hline & Ardisia elliptica (Myrsinaceae) (i) & 13 & $\mathrm{P}$ & $0.96 \pm 0.62$ & $59.1 \pm 3.6$ \\
\hline & Cassia fistola (Fabaceae) (ni) & 24 & $P$ & $0.48 \pm 0.44$ & $51.6 \pm 9.4$ \\
\hline & Colocasia gigantea (Araceae) (i) & 8 & $\mathrm{P}$ & $0.46 \pm 0.55$ & $26.3 \pm 6.4$ \\
\hline & Diospyrus durionoides (Ebenceae) (i) & 19 & $\mathrm{P}$ & $0.19 \pm 0.21$ & $43.4 \pm 7.7$ \\
\hline & Ellophyllus rubi (Sapinaceae) (i) & 13 & $\mathrm{P}$ & $0.78 \pm 0.68$ & $27.4 \pm 6.4$ \\
\hline & Peltophorum pterocarpum (Fabaceae) (i) ${ }^{1}$ & 22 & $\mathrm{P}$ & $0.63 \pm 0.34$ & $36.4 \pm 13.8$ \\
\hline T. collina & A. jiringa & 10 & $\mathrm{~N}$ & $1.11 \pm 0.99$ & $47.8 \pm 9.9$ \\
\hline T. fimbriata melanotricha & A. elliptica & 4 & $\mathrm{P}$ & $1.81 \pm 1.29$ & $42.1 \pm 11.2$ \\
\hline \multirow[t]{3}{*}{ T. haematoptera } & A. elliptica & 7 & $P$ & $0.93 \pm 1.20$ & $44.0 \pm 10.7$ \\
\hline & Dillenia excelsa (Dilleniaceae) (i) ${ }^{1}$ & 27 & $\mathrm{P}$ & $0.99 \pm 0.75$ & $25.8 \pm 10.7$ \\
\hline & Mallotus spec. (Euphorbiaceae) (i) & 36 & $P$ & $0.69 \pm 0.68$ & $42.4 \pm 16.1$ \\
\hline \multirow[t]{2}{*}{ T. itama } & Averrhoa carambola (Oxalidaceae) (i) ${ }^{1}$ & 13 & $\mathrm{~N}$ & $0.76 \pm 0.59$ & $54.4 \pm 6.0$ \\
\hline & C. fistola ${ }^{1}$ & 12 & $\mathrm{~N} ?+\mathrm{P}$ & $0.71 \pm 0.33$ & $46.3 \pm 12.3$ \\
\hline \multirow[t]{5}{*}{ T. laeviceps } & A. pyramidalis & 14 & $\mathrm{P}$ & $0.59 \pm 0.48$ & $49.5 \pm 15.6$ \\
\hline & D. durionoides & 17 & $\mathrm{P}$ & $0.12 \pm 0.20$ & $60.4 \pm 2.3$ \\
\hline & Ixora javanica (Rubiaceae) (ni) & 19 & $P$ & $0.23 \pm 0.24$ & $57.0 \pm 6.0$ \\
\hline & Pipturus spec. (Urticaceae) (ni) & 14 & $P$ & $0.24 \pm 0.28$ & $47.6 \pm 9.9$ \\
\hline & Wedelia trilobata (Asteraceae) (ni) & 19 & $\mathrm{P}$ & $0.29 \pm 0.22$ & $49.1 \pm 9.1$ \\
\hline T. melanocephala & D. durionoides & 10 & $\mathrm{P}$ & $0.16 \pm 0.15$ & $50.6 \pm 5.8$ \\
\hline
\end{tabular}

${ }^{1}$ Observed in 2004 (pollen load not quantified), all other observations from 2005.

assessment presented here was an adequate measurement for pollen loads. We examined the overall correlation between crop load volume and pollen load $(L)$ of individual workers captured on flowers. For this analysis, Spearman's correlation coefficients were obtained for each combination of bee species and flower species, and used in a standard meta-analysis algorithm to yield the mean effect size across these combinations (MetaWin 2.0, Fisher's $z$-transformation, 95\% confidence intervals based on bootstrapping using $10^{4}$ iterations, biascorrected).

The proportion of sugar probably recycled for pollen collection was estimated for each colony by dividing the mean sugar load $(\mu \mathrm{g})$ per individual bee returning with nectar only or with nectar and resin by the net sugar used during a foraging trip (mean $\mu \mathrm{g}$ sugar carried by a departing bee minus mean $\mu \mathrm{g}$ sugar carried by a returning individual with pollen loads including those returning with pollen loads but empty crops). This ratio compares the sugar 'loss' caused by a single pollen foraging individual with the gain of a single nectar foraging individual. Thus, the relative frequency of nectar vs. pollen foragers has to be taken into account for a colony-level estimation of the proportion of sugar used for pollen collection. This simplified calculation is based on several assumptions, e.g. that no nectar is collected by pollen foragers (validated by direct observations at pollen plants) and that the proportion of nectar and pollen foragers remains constant over the time span nectar is stored in the colony. Therefore, results must be regarded as crude estimates.

In addition to crop nectar volume and total sugar concentration, we checked sugar composition and total amino acid concentration of crop contents from a few selected departing and returning 


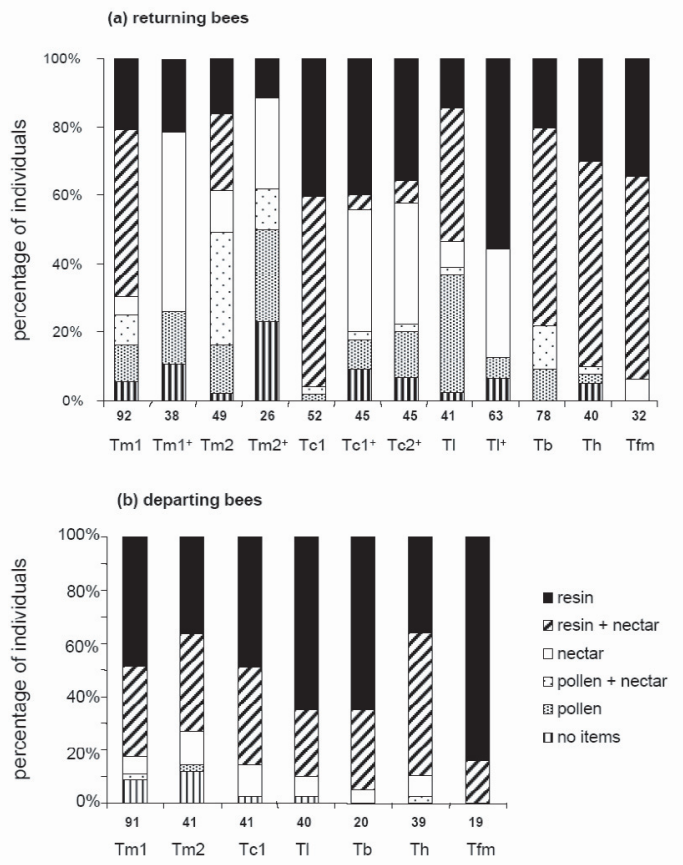

Figure 1. Proportion of items carried by bee individuals that (a) returned to their nests and (b) departed from their nests (sample size gives the number of individuals investigated; $\mathrm{Tm}=$ Trigona melanocephala (colony 1 and 2 ), $\mathrm{Tc}=T$. collina, $\mathrm{Tl}=T$. laeviceps, $\mathrm{Tb}=T$. binghami, $\mathrm{Th}=T$. haematoptera, $\mathrm{Tfm}=T$. fimbriata melanotricha,${ }^{+}=$observed in 2004).

workers. Sugar composition was analysed by high performance liquid chromatography (HPLC). Total amino acid concentration was estimated semiquantitatively using a ninhydrine-staining technique established by Baker and Baker (1975). No obvious differences between departing and returning workers were detected. Glucose, fructose and sucrose were the most common carbohydrates, while mannose, arabinose and maltose occurred in a few cases only. Total amino acid concentrations of crop contents varied strongly among colonies, but not significantly between departing and returning workers within a colony (Mann-Whitney U-tests for five colonies, all $Z \leq 1.9, P \geq 0.07$, crop contents measured from a total of 48 departing and 84 returning bees).

\subsection{Mark-recapture of individual bees}

In order to examine individual foraging strategies, we marked returning $T$. melanocephala foragers: 50 returning individuals with full pollen loads were marked on the thorax with a water soluble colour before entering the nest. After 1 to 2 hours, we were able to recapture 12 individuals when they were about to depart from the entrance tube. Two days later, when the colour from the first marking experiment had completely disappeared, returning bees with full nectar loads were marked, 13 of which were later recaptured before departure. Crop contents and corbicular loads of all recaptured individuals were measured as described above.

\section{RESULTS}

\subsection{Loads carried by returning bees}

All Trigona species foraged for nectar, pollen and resin (Fig. 1a). Collection of nectar was common in all species at the time of the study. Pollen collecting was particularly frequent in T. binghami, T. laeviceps and both $T$. melanocephala colonies. Resin was collected 
to a great extent by T. binghami, T. collina, T. fimbriata and T. haematoptera. Twentyfive percent of the individuals returning with pollen loads carried measurable nectar in their crop (all species pooled). If nectar loads were present in bees that carried normal pollen loads, their volume was relatively small (less than $1 \mu \mathrm{L}$ ). On the other hand, most bees (of all species except $T$. binghami) with substantial nectar loads carried no pollen or only minute pollen loads. Many individual bees carried both nectar and resin during the same foraging trip, often including large nectar loads which did not differ significantly in volume from that of sole nectar loads $(t \leq 2.2, P \geq$ $0.07)$, except in one T. melanocephala $(t=3.7$, $P=0.02)$ colony and in $T$. fimbriata $(t=4.8$, $P=0.005)$ where average amounts of nectar were lower when resin loads were also present. However, amounts of resin carried by those workers whose crops contained nectar were usually small (covering less than one quarter of the corbicula) compared to large resin loads of bees that returned with resin and empty crops.

\subsection{Loads carried upon departure and during foraging}

In all species studied, between $10 \%$ ( $T$. fimbriata) and $70 \%$ (T. haematoptera) of the departing bees carried nectar in their crop (Fig. 1b). Crop nectar volume carried by departing bees was significantly lower than crop contents of returning bees that foraged for nectar only or nectar and resin (significant in each species, $t \geq 4.6, P<0.001$ ) (Tab. II). For $T$. melanocephala, sugar concentration of nectar carried by departing workers was significantly higher than that of nectar harvested by returning workers, while in the other colonies, no significant difference was found (Tab. II). As in many returning bees, departing bees transported nectar either alone or in combination with resin. Many bees also departed with small loads of resin only. Only a few individuals had no load or carried small amounts of pollen when leaving their nests (Fig. 1b).

On 11 of 14 plant species investigated, pollen was most likely the only resource col- lected by bees (Tab. I), although on at least some of these plants nectar would theoretically have been accessible. However, up to $1 \mu \mathrm{L}$ nectar could often be extracted from the crop of foraging bees. Crop contents were usually highly concentrated (between 40 and 60\% sucrose equivalents; Tabs. I, and II). The only exception was T. binghami whose crops carried a comparatively low sugar concentration when foraging on Ellophyllus rubi.

Since the pollen load increases during the course of a foraging trip, we analysed whether an increased amount of pollen on the corbicula was associated with a successive impoverishment of nectar from the crop. This analysis was performed across all 14 combinations of bees and plant species examined in 2005 where bees collected pollen (see Tab. I). Overall, a significantly negative correlation was found between the size of pollen loads and nectar volume carried in the crop (mean ztransformed Spearman's $r_{S}=-0.34,95 \%$ confidence intervals: -0.54 to -0.13$)$. One example is shown in Figure 2 for T. binghami, for which pollen loads have been calibrated as weight (see Sect. 2.2).

In some colonies (Trigona collina, $T$. haematoptera, T. laeviceps, T. melanocephala colony 1), pollen gathering bees were estimated to use between $45 \%$ and $90 \%$ of the crop volume at departure for pollen collection ([mean $\mu \mathrm{L}$ sugar carried in crops from departing bees minus mean $\mu \mathrm{L}$ from returning bees with pollen loads] divided by mean $\mu \mathrm{L}$ from departing bees) (Tab. II). In two colonies (T. binghami, T. melanocephala colony 2), workers returning with pollen loads still carried relatively large amounts of nectar in their crops, sometimes exceeding those of departing bees (Tab. II). This may suggest that such bees harvest both pollen and nectar simultaneously during the same foraging trip. Given the frequency of departing and returning bees with nectar loads (Fig. 1), we estimate that between $4 \%$ to $59 \%$ (mean $29 \%$ ) of the total sugar harvest was allocated to pollen collection (Tab. II). For example, crop loads of T. laeviceps workers contained on average $184 \mu \mathrm{g}$ sugar upon departure of which $23 \mu \mathrm{g}$ remained after returning with pollen, while each nectar harvesting worker brought $464 \mu \mathrm{g}$ 
Table II. Volume and sugar concentration of crop loads measured in departing and returning Trigona workers captured at nests and workers captured on flowers. Bees returning with nectar include those returning with nectar and resin. Number of workers $(n)$, observation hours $(h)$ and days $(d)$, and crop loads $(\mu \mathrm{L}$ solution and \% sugar) shown for the two years separately (mean $\pm \mathrm{SD}$ ). Last column $(P R)$ shows estimated proportion of nectar intake that is recycled for pollen foraging (see Methods). Crop loads were compared between foragers returning with nectar versus departing workers with nectar, significance level shown $\left({ }^{N S}\right.$ not significant, $* * * P<0.001)$ for Walsh's $t$-test.

\begin{tabular}{|c|c|c|c|c|c|c|}
\hline Trigona sp. (colony) & Foragers & $n$ & $h(d)$ & Crop load $[\mu \mathrm{L}]$ & Sugar $[\%]$ & $P R$ \\
\hline \multicolumn{7}{|l|}{ Year: 2004} \\
\hline \multirow[t]{3}{*}{ T. collina $(1)$} & returning with nectar & 16 & $3(3)$ & $3.60 \pm 1.67$ & $32.5 \pm 13.1$ & \\
\hline & returning with pollen & $5(4)^{1}$ & $3(3)$ & $0.46 \pm 1.03$ & 49 & \\
\hline & on flowers (pooled) & 1 & $3(5)$ & 0.1 & 40 & \\
\hline \multirow[t]{2}{*}{ T. collina (2) } & returning with nectar & 16 & $2(2)$ & $2.79 \pm 1.46$ & $38.5 \pm 10.6$ & \\
\hline & returning with pollen & $8(7)^{1}$ & $2(2)$ & $0.5 \pm 1.4$ & 30 & \\
\hline T. haematoptera & on flowers (pooled) & 40 & $4(10)$ & $0.98 \pm 0.73$ & $26.9 \pm 12.2$ & \\
\hline \multirow[t]{3}{*}{ T. laeviceps } & returning with nectar & 15 & $5(5)$ & $0.65 \pm 0.35$ & $25.0 \pm 11.6$ & \\
\hline & returning with pollen & $4(4)^{1}$ & $5(5)$ & 0 & - & \\
\hline & on flowers (pooled) & 1 & & 0.1 & 60 & \\
\hline \multirow[t]{3}{*}{ T. melanocephala (1) } & returning with nectar & 18 & $3(2)$ & $1.46 \pm 1.02$ & $24.9 \pm 6.2$ & \\
\hline & returning with pollen & $6(6)^{1}$ & $3(2)$ & 0 & - & \\
\hline & on flowers (pooled) & 1 & & 0.3 & 47 & \\
\hline \multirow[t]{2}{*}{ T. melanocephala (2) } & returning with nectar & 9 & $2(3)$ & $0.33 \pm 0.58$ & $32.9 \pm 18.4$ & \\
\hline & returning with pollen & $11(8)^{1}$ & $2(3)$ & $0.29 \pm 0.60$ & $37.7 \pm 20.6$ & \\
\hline T. binghami & on flowers (pooled) & 22 & $4(5)$ & $0.63 \pm 0.35$ & $36.4 \pm 14.1$ & \\
\hline \multicolumn{7}{|l|}{ Year: 2005} \\
\hline \multirow[t]{4}{*}{ T. binghami } & returning with nectar & 50 & $4(2)$ & $1.79 \pm 1.36$ & $27.4 \pm 13.2$ & \\
\hline & returning with pollen & $19(7)^{1}$ & & $0.76 \pm 1.01$ & $32.0 \pm 13.0$ & \\
\hline & departing with nectar & 7 & $2(1)$ & $0.38 \pm 0.33 * * *$ & $36.7 \pm 17.0^{N S}$ & $38 \%^{2}$ \\
\hline & on flowers (pooled) ${ }^{3}$ & 97 & $27(9)$ & $0.73 \pm 0.52$ & $44.3 \pm 14.2$ & \\
\hline \multirow[t]{4}{*}{ T. collina (1) } & returning with nectar & 29 & $4(1)$ & $3.16 \pm 2.24$ & $48.6 \pm 16.7$ & \\
\hline & returning with pollen & $2(1)^{1}$ & & $0.23 \pm 0.32$ & 60 & \\
\hline & departing with nectar & 20 & $4(1)$ & $0.47 \pm 0.31 * * *$ & $46.3 \pm 22.6^{N S}$ & $14 \%$ \\
\hline & on flowers (pooled) ${ }^{3}$ & 10 & $14(3)$ & $1.11 \pm 0.99$ & $47.8 \pm 9.9$ & \\
\hline \multirow[t]{4}{*}{ T. fimbriata melanotr. } & returning with nectar & 21 & $3(1)$ & $4.27 \pm 2.12$ & $19.2 \pm 2.1$ & \\
\hline & returning with pollen & 0 & & - & - & \\
\hline & departing with nectar & 3 & $3(1)$ & $0.97 \pm 0.73 * * *$ & $18.0 \pm 0.9^{N S}$ & $4 \%^{2}$ \\
\hline & on flowers (pooled) ${ }^{3}$ & 4 & $4(2)$ & $1.81 \pm 1.29$ & $42.1 \pm 11.2$ & \\
\hline \multirow[t]{4}{*}{ T. haematoptera } & returning with nectar & 24 & $5(1)$ & $4.20 \pm 3.37$ & $29.5 \pm 14.6$ & \\
\hline & returning with pollen & $3(2)^{1}$ & & $0.37 \pm 0.63$ & 20 & \\
\hline & departing with nectar & 25 & $4(1)$ & $0.93 \pm 0.74 * * *$ & $24.5 \pm 9.4^{N S}$ & $15 \%$ \\
\hline & on flowers (pooled) ${ }^{3}$ & 42 & $7(2)$ & $0.95 \pm 0.76$ & $42.6 \pm 15.4$ & \\
\hline \multirow[t]{4}{*}{ T. laeviceps } & returning with nectar & 19 & $4(1)$ & $1.22 \pm 0.80$ & $40.5 \pm 17.7$ & \\
\hline & returning with pollen & $15(14)^{1}$ & & $0.03 \pm 0.13$ & 54 & \\
\hline & departing with nectar & 13 & $4(1)$ & $0.33 \pm 0.19 * * *$ & $46.5 \pm 7.4^{N S}$ & $24 \%$ \\
\hline & on flowers (pooled) ${ }^{3}$ & 121 & $32(10)$ & $0.37 \pm 0.33$ & $51.8 \pm 11.2$ & \\
\hline
\end{tabular}


Table II. Continued.

\begin{tabular}{lcccccc}
\hline Trigona sp. (colony) & Foragers & $n$ & $h(d)$ & Crop load $[\mu \mathrm{L}]$ & Sugar $[\%]$ & $P R$ \\
\hline T. melanocephala (1) & returning with nectar & 54 & $7(2)$ & $1.78 \pm 1.25$ & $33.0 \pm 17.9$ & \\
& returning with pollen & $20(11)^{1}$ & & $0.37 \pm 0.77$ & $43.8 \pm 4.6$ & \\
& departing with nectar & 39 & $7(2)$ & $0.67 \pm 0.71^{* * *}$ & $50.8 \pm 11.3^{* * *}$ & $59 \%$ \\
& on flowers (pooled) & 10 & $12(6)$ & $0.20 \pm 0.15$ & $50.6 \pm 5.7$ & \\
T. melanocephala (2) & returning with nectar & 28 & $4(1)$ & $1.54 \pm 1.28$ & $33.0 \pm 10.9$ & \\
& returning with pollen & $26(7)^{1}$ & & $0.91 \pm 1.12$ & $31.5 \pm 8.6$ & \\
& departing with nectar & 20 & $4(1)$ & $0.27 \pm 0.17^{* * *}$ & $54.0 \pm 5.4^{* * *}$ & $50 \%^{2}$ \\
\hline
\end{tabular}

${ }^{1}$ Number of workers returning with pollen and empty crops in parentheses (included in calculation of mean crop load and $P R$, but not mean sugar concentration).

${ }^{2}$ Crop loads of returning bees with nectar and pollen larger than those of departing bees (or no data available for returning bees with pollen), thus $P R$ estimation based on assumption that bees use $75 \%$ of their sugar weight carried upon departure during pollen foraging (mean value of the remaining four colonies).

${ }^{3}$ Colonies were not distinguished. Workers with empty crops were excluded.

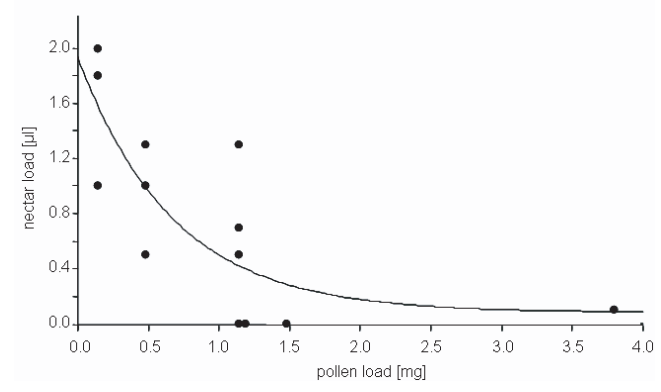

Figure 2. Correlation between pollen and nectar load in Trigona binghami on Ellophyllus rubi (exponential function fitted as: nectar load $[\mu \mathrm{L}]=$ $0.08+\exp (0.62+(-1.49) \times$ pollen load $[\mathrm{mg}]) ; r=$ 0.62 ; weight of pollen load recalculated from linear calibration shown in the Methods section).

into the colony. The proportion of workers departing versus returning with nectar (or nectar and resin) was $32 \%$ versus $46 \%$, respectively (Fig. 1). The estimated proportion of recycled nectar yields $(184 \mu \mathrm{g}-23 \mu \mathrm{g})$. $32 \% /(464 \mu \mathrm{g} \cdot 46 \%)=0.24($ Tab. II $)$.

\subsection{Individual foraging patterns}

The marked and recaptured $T$. melanocephala individuals showed a clear relationship between pollen collection and nectar and resin load upon departure. All
12 departing bees that had previously collected pollen carried a small amount of highly concentrated nectar in their crop when leaving their nest (mean \pm SD amount of nectar: $0.38 \mu \mathrm{L} \pm 0.25$, sugar concentration $55.5 \% \pm$ 8.5). In contrast, none of the 13 previous nectar foragers departed with any nectar in their crop. The proportion of departing bees with and without nectar differed significantly between the two groups $\left(\chi^{2}=26\right.$, df $=1$, $P<0.001$ ). Most nectar foragers had small amounts of resin on their corbiculae when first captured. Twelve of the 13 recaptured workers also departed with some resin, whereas no resin could be found on the corbiculae of the pollen foragers above.

\subsection{Observations on Archidendron jiringa}

T. binghami and T. collina collected both floral and extrafloral nectar on Archidendron jiringa, the only plant species in this study where floral nectar was observed to be the main resource collected on flowers. While floral nectar was taken up with the bee's tongue, the viscous extrafloral nectar of $A$. jiringa was attached to the corbiculae by continuously scrubbing the hind legs over an extrafloral nectary. Crop contents of foragers on $A$. jiringa had a similar (T. collina) or higher 
(T. binghami) sugar concentration than other conspecific foragers caught at nest entrances upon departure or return (Tabs. I and II).

\section{DISCUSSION}

\subsection{Utilisation of nectar for pollen foraging}

Our results suggest that stingless bees use a substantial amount of the nectar storage from their nest for the purpose of pollen collecting. Bees captured at flowers usually carried nectar in their crop, even when they solely harvested pollen. Many bees departed from their nest with partly filled crops, typically containing about one-quarter of the mean crop load of a returning nectar forager. This crop content declined with an increasing pollen load during the foraging trip. When foragers returned with pollen loads, about three-quarters of them had empty crops, indicating that they typically use up their entire nectar load. In the remaining pollen-collecting bees where crops still did contain (remaining or additionally collected) nectar, these nectar loads were usually small compared to nectar foragers. The markrecapture experiment showed that only pollen foragers of Trigona melanocephala departed with highly concentrated nectar in their crop, whereas none of the nectar foragers departed with any nectar.

All these findings are consistent with a specific use of nectar for pollen foraging either to meet metabolic costs of pollen harvesting (fuel hypothesis) and/or for adhesion of pollen loads (glue hypothesis). The fuel hypothesis infers that pollen foragers may require stored nectar as energy source during their foraging trip unlike nectar harvesting bees which refill their crops during foraging. These requirements should be particularly pronounced for bees foraging on flowers that offer only poor nectar or no nectar at all, in cases where bees specialise in harvesting pollen, or when pollen foraging requires longer times or distances. The glue hypothesis is supported by studies on honeybees. Roulston et al. (2000) showed by comparing pollen collected from flowers versus pollen collected from honeybees that half or more of the dry mass of pollen loads can be attributed to the addition of nectar carbohydrates, hence the contribution of nectar to the wet mass of pollen loads is even higher. Although nectar in pollen loads has not been measured in the present study, the pollen loads of stingless bee foragers (especially T. melanocephala) are often very moist, indicating a high nectar content. Evidence for utilisation of nectar for pollen collection was found in six of the seven Trigona species, except $T$. binghami. This behaviour may lead to a significant removal of the colony's total sugar harvest: proportions estimated in our study range between $5 \%$ and $36 \%$ of the total nectar intake in four colonies. For the colony as a whole, however, this nectar is not lost because it re-enters the colony with the harvested pollen.

Pollen foraging individuals usually carry a lower volume of nectar than individuals which return from nectar foraging, but this stored and/or processed nectar often has a higher sugar concentration than the harvested one. Since workers should have very poor capabilities to concentrate their harvested nectar during a foraging trip (Roubik et al., 1995), more concentrated stored nectar may be particularly suitable for pollen foraging. These findings agree with results previously found in Apis mellifera. Calderone and Page (1992) measured much higher volumes and lower concentrations of crop nectar (mean values: $25 \mu \mathrm{L}, 37 \%$ ) in returning honeybee foragers than Gary and Lorenzen (1976) in departing honeybee foragers elsewhere $(0.7 \mu \mathrm{L}, 49 \%)$. Future studies may reveal whether the amount or concentration of nectar carried upon departure reflects the anticipated pollen properties, flight distance and/or availability of additional floral nectar on the flower to be visited, and whether it varies systematically among bee and/or flower species. This seems likely since pollen loads of different plant species may vary strongly in liquidity and compaction (T. Eltz, unpubl. data).

\subsection{Mixed-items foraging}

While non-tropical honeybees and bumblebees were reported to regularly collect both 
pollen and nectar during a single foraging trip (Benedek, 1976; Plowright and Galen, 1985; Worswick, 1988; Rana et al., 1997), such mixed foraging did not seem to be common in several colonies of stingless bees (except $T$. binghami). Our results generally caution against a possible misinterpretation of putative 'mixed foraging' based on observations of foraging or returning bees. Only when quantitative comparisons with loads of departing bees are considered, crop contents of returning or foraging bees may be more reliably assigned to have been collected during the same foraging trip or not. Considering this comparison, stingless bee workers may typically specialise on either pollen or nectar collection, while mixed foraging appears to be rather exceptional at least for the colonies and during the time period of our study. Under certain circumstances, task specialisation of individuals may guarantee a more efficient exploitation of a valuable pollen or nectar resource respectively (Oster and Wilson, 1978). This dichotomy of nectar and pollen collection may be also driven by a more patchy distribution of flowers in tropical forests and/or by a higher specificity of floral rewards (e.g., flowers offering both suitable pollen and nectar may be rare). However, since pollen foraging may be more predominant during the early morning hours (Roubik and Buchmann, 1984), some cases of mixed foraging may have escaped our notice. Resin was collected by all observed Trigona species. However, the function of resin loads carried by nectar foraging bees (but not on departing pollen foragers, at least in the marked T. melanocephala) remains obscure and requires further investigations. Besides resin, sticky extrafloral nectar was observed to be collected on the corbiculae from Archidendron jiringa, a behaviour not reported previously.

Further studies are needed to achieve a better understanding of diurnal and seasonal changes in foraging patterns. Variation in quality and quantity of items harvested by stingless bees was pronounced among the colonies and species, but also across the two years in our study. However, our results only represent a relatively brief snapshot of the bees' activity. Other studies demonstrated a substantial fluc- tuation of foraging and food storage of tropical stingless bees across seasons (Roubik et al., 1986; Roubik, 1989; Eltz et al., 2001) or during the course of the day (Inoue et al., 1985). The variation of nectar and pollen intake, harvested nectar concentration and perhaps the incidence of mixed pollen-nectar foraging strategies across colonies may be strongly related to spatio-temporal availability of resources (Inoue et al., 1985; Eltz, 2004) and niche partitioning (Nagamitsu et al., 1999) and thus require further investigations.

\section{ACKNOWLEDGEMENTS}

We thank Andrea Hilpert for technical assistance, Eva Reisberg and the Institute of Botany, University of Würzburg, for kindly providing HPLC measurements and Norbert Schneider for construction of the modified hand vacuum cleaner to capture bees. Comments from two anonymous reviewers greatly improved the quality of the paper. We acknowledge EPU Malaysia and Danum Valley Management Committee for permission to conduct research, the British Royal Society and the DVFC staff for logistic support and the DAAD for financial travel support of S.L. and K.D.

Charges en nectar, pollen et résine des abeilles sans aiguillon et utilisation du nectar stocké par les butineuses de pollen.

abeille sans aiguillon / Trigona / Apidae / Meliponini / comportement de butinage / nectar/ pollen / résine

Zusammenfassung - Nektar-, Pollen- und Harzmengen von Stachellosen Bienen und Benutzung des aufgespeicherten Nektar durch Pollensammlerinnen. In dieser Studie wurde das individuelle Sammelverhalten von Arbeiterinnen bei sechs Arten der Gattung Trigona (Apidae, Meliponinae) in einem Tieflandregenwald Borneos (Sabah, Malaysia) untersucht. Von Honigbienen und Hummeln ist bekannt, dass Nektar und Pollen teilweise während desselben individuellen Sammelflugs geerntet werden. Das Vorhandensein einer solchen „Mischsammelstrategie" wurde jedoch bei Stachellosen Bienen bislang nicht genauer untersucht. Daher wurden quantitative Daten zu Nektar-, Pollen- und Harzmengen aufgenommen und verglichen zwischen aus dem Nest ausfliegenden Arbeiterinnen, solchen an Blüten, und bei ins Nest zurückkehrenden Arbeiterinnen. Alle untersuchten Kolonien trugen Nektar, Pollen und Harz ein (Abb. 1a). Ein 
Viertel der Arbeiterinnen, die Pollen eintrugen, wiesen kleine Nektarmengen in ihren Honigmägen auf. Bienen mit großen Nektarmengen trugen dagegen keinen oder nur sehr geringe Mengen Pollen ein. Folglich gibt es nur einen geringen Anteil potentieller „Mischsammlerinnen“. Der Nektar in den Honigmägen von Pollensammlerinnen wird vermutlich selten während desselben Ausflugs an Blüten gesammelt, sondern stellt einen Vorrat dar, der bereits aus dem Nest mitgenommen wurde. Bei den sechs Arten hatten zwischen $10 \%$ und $70 \%$ der ausfliegenden Bienen Nektar im Honigmagen (Abb. 1b). Diese Nektarfüllung war signifikant kleiner als bei heimkehrenden Nestgenossen, die allein Nektar eintrugen (Tab. II). Bei den meisten Pflanzenarten konnte Trigona lediglich beim Sammeln von Pollen, nicht aber Nektar beobachtet werden (11 von 14 Pflanzenarten, Tab. I). Jedoch konnte bei diesen Arbeiterinnen bis $\mathrm{zu} 1 \mu \mathrm{L}$ hoch konzentrierten Nektars im Honigmagen nachgewiesen werden. Das Volumen dieses Nektarvorrats verringert sich offenbar während des Sammelflugs mit zunehmender Pollenladung (Abb. 2). Um die individuellen Strategien bei Trigona melanocephala genauer zu untersuchen, markierten wir einzelne zum Nest heimkehrende Pollen- und Nektarsammlerinnen und fingen diese beim Verlassen des Nests wieder ab. Alle vorherigen Pollensammlerinnen trugen hochkonzentrierten Nektar in ihren Honigmägen, jedoch keine der Nektarsammlerinnen. Diese Befunde stützen daher die Hypothese, dass Nektar aus dem Nest gezielt für das Pollensammeln verwendet wird. Nektar wird entweder für metabolische Kosten beim Pollensammeln oder zur Befestigung der Pollenladungen an den Körbchen verwendet. Arbeiterinnen Stachelloser Bienen spezialisierten sich häufig auf den Eintrag von Pollen oder Nektar. Mischsammelstrategien sind dagegen die Ausnahme. Unsere Untersuchung zeigt, dass Rückschlüsse über Mischsammelstrategien problematisch sind, die allein auf Beobachtungen heimkehrender oder fouragierender Bienen basieren, und ein quantitativer Vergleich mit ausfliegenden Bienen notwendig ist.

\section{Trigona / Sammelverhalten / Pollen / Nektar / Harz}

\section{REFERENCES}

Baker H.G., Baker I. (1975) Studies of nectarconstitution and pollinator plant coevolution, in: Gilbert L.E., Raven P.H. (Eds.), Coevolution of Animals and Plants. University of Texas Press, Austin, Texas, pp. 100-140.

Benedek P. (1976) Behaviour of honeybees in red clover fields throughout flowering period, $\mathrm{Z}$. Angew. Entomol. 80, 213-219.
Benjamini Y., Hochberg Y. (1995) Controlling the false discovery rate: a practical and powerful approach to multiple testing, J. R. Stat. Soc. Ser. B 57, 289-300.

Biesmeijer J.C., Toth E. (1998) Individual foraging, activity level and longevity in the stingless bee Melipona beecheii in Costa Rica (Hymenoptera, Apidae, Meliponinae), Insectes Soc. 45, 427-443.

Biesmeijer J.C., Richter J.A.P., Smeets M.A.J.P., Sommeijer M.J. (1999) Niche differentiation in nectar-collecting stingless bees: the influence of morphology, floral choice and interference competition, Ecol. Entomol. 24, 380-388.

Calderone N.W., Page R.E. (1992) Effects of interactions among genotypically diverse nestmates on task specialization by foraging honey-bees (Apis mellifera), Behav. Ecol. Sociobiol. 30, 219-226.

Corlett R.T. (2004) Flower visitors and pollination in the Oriental (Indomalayan) Region, Biol. Rev. 79, 497-532.

Eltz T. (2004) Spatio-temporal variation of apine bee attraction to honeybaits in Bornean forests, J. Trop. Ecol. 20, 317-324.

Eltz T., Brühl C.A., van der Kaars S., Chey V.K., Linsenmair K.E. (2001) Pollen foraging and resource partitioning of stingless bees in relation to flowering dynamics in a Southeast Asian tropical rainforest, Insectes Soc. 48, 273-279.

Eltz T., Brühl C.A., Görke C. (2002) Collection of mold (Rhizopus sp.) spores in lieu of pollen by the stingless bee Trigona collina, Insectes Soc. 49, 28-30.

Gary N.E., Lorenzen K. (1976) A method for collecting the honey-sac contents from honeybees, J. Apic. Res. 15, 73-76.

Inoue T., Salmah S., Abbas I., Yusuf E. (1985) Foraging behavior of individual workers and foraging dynamics of colonies of three Sumatran stingless bees, Res. Popul. Ecol. 27, 373-392.

Marsh C.W., Greer A.G. (1992) Forest land-use in Sabah, Malaysia: an introduction to Danum Valley, Phil. Trans. R. Soc. London B 335, 331-339.

Nagamitsu T., Inoue T. (1997) Aggressive foraging of social bees as a mechanism of floral resource partitioning in an Asian tropical rainforest, Oecologia $110,432-439$.

Nagamitsu T., Momose K., Inoue T., Roubik D.W. (1999) Preference in flower visits end partitioning in pollen diets of stingless bees in an Asian tropical rain forest, Res. Pop. Ecol. 41, 195-202.

Oster G.F., Wilson E.O. (1978) Caste and ecology in the social insects, Princeton University Press, Princeton, NJ. 
Pierrot L.-M., Schlindwein C. (2003) Variation in daily flight activity and foraging patterns in colonies of urucu: Melipona scutellaris Latreille (Apidae, Meliponini), Rev. Bras. Zool. 20, 565-571.

Plowright R.C., Galen C. (1985) Landmarks or obstacles - the effects of spatial heterogeneity on bumble bee foraging behavior, Oikos 44, 459-464.

Rana V.K., Raj D., Kaushik R. (1997) Comparative foraging activity of Apis mellifera L. and Apis cerana indica $\mathrm{F}$. on rapeseed bloom, J. Entomol. Res. 21, 59-64.

Roubik D.W. (1989) Ecology and natural history of tropical bees, Cambridge University Press, New York.

Roubik D.W. (1993) Tropical pollinators in the canopy and understory - field data and theory for stratum preferences, J. Insect Behav. 6, 659-673.

Roubik D.W., Buchmann S.L. (1984) Nectar selection by Melipona and Apis mellifera (Hymenoptera: Apidae) and the ecology of nectar intake by bee colonies in a tropical forest, Oecologia 61, 1-10.

Roubik D.W., Moreno J.E., Vergara C., Wittmann D. (1986) Sporadic food competition with the African honey bee: projected impact on Neotropical social bees, J. Trop. Ecol. 2, 97-111.

Roubik D.W., Yanega D., Aluja M., Buchmann S.L., Inouye D.W. (1995) On optimal nectar foraging by some tropical bees (Hymenoptera, Apidae), Apidologie 26, 197-211.
Roulston T.H., Cane J.H., Buchmann S.L. (2000) What governs protein content of pollen: pollinator preferences, pollen-pistil interactions, or phylogeny? Ecol. Monogr. 70, 617-643.

Sommeijer M.J., De Bruijn L.L.M., Van de Guchte C. (1985) The social food flow within the colony of a stingless bee, Melipona favosa (F.), Behaviour 92, 39-58.

Sommeijer M.J., De Rooy G.A., Punt W., De Bruijn L.L.M. (1983) A comparative study of foraging behavior and pollen resources of various stingless bees (Hym., Meliponinae) and honeybees (Hym., Apinae) in Trinidad, West Indies, Apidologie 14, 205-224.

Wille A. (1983) Biology of the stingless bee, Annu. Rev. Entom. 28, 41-46.

Wilms W., Imperatriz-Fonseca V.L., Engels W. (1996) Resource partitioning between highly eusocial bees and possible impact of the introduced Africanized honey bee on native stingless bees in the Brazilian Atlantic rainforest, Stud. Neotrop. Fauna Environ. 31, 137-151.

Worswick P.V. (1988) Comparison of nectar foraging efficiency in the Cape honeybee, Apis mellifera capensis Escholtz, and the African honeybee, Apis mellifera adansonii Latreille, in the western Cape Province, S. Afr. J. Zool. 23, 124-127. 